\title{
NATO: Kajian Implementasi Containment Policy Bidang Militer di Eropa (1949-1991)
}

\author{
YULITA DEWI PURMINTASARI \\ Dosen Jurusan Pendidikan Sejarah STKIP PGRI Pontianak \\ email : yulita.dewi46@yahoo.com
}

\begin{abstract}
Abstrak
Tujuan penelitian ini adalah untuk mengkaji kebijakan pembendungan komunisme yang dilakukan Amerika Serikat selama Perang Dingin dalam bidang militer. Menggunakan metode sejarah kritis yang terdiri dari empat langkah yaitu heuristik, kritik sumber, interpretasi dan historiografi. Hasil penelitian menunjukkan bahwa dalam usaha membendung komunisme Uni Soviet, terutama dalam bidang militer Amerika Serikat mendirikan pakta pertahanan bersama di Eropa, yaitu NATO. Berdirinya NATO mendapat respon dari Uni Soviet dengan mendirikan Pakta Warsawa sebagai tandingan NATO. Selain itu NATO juga memicu Amerika Serikat untuk mendirikan organisasi yang serupa sebagai usaha membendung komunisme Uni Soviet. NATO dan Pakta Warsawa sebagai simbol Perang Dingin saling unjuk kekuatan, baik dalam senjata konvensional maupun nuklir. Namun persaingan kedua pihak membawa kecemasan, sehingga diadakan perundingan-perundingan untuk mengurangi persaingan kekuatan tersebut. Runtuhnya Uni Soviet dan bubarnya Pakta Warsawa, membuat NATO kehilangan lawan dan arah kebijakannya.
\end{abstract}

Kata kunci : NATO, Containment Policy

\begin{abstract}
The objective of this research is to study the communism containment policy performed by the United States during the Cold War in the military field. This research uses critical history method that consists of heuristics, criticism of sources, interpretation and historiography. The results show that the Soviet Union, particularly in the areas of the United States military established a mutual defense pact in Europe, namely NATO in order to stem communism. The establishment of NATO got a response from the Soviet Union by establishing the Warsaw Pact as a rival to NATO. Besides, NATO also sparked the United States to set up a similar organization as an effort to stem Soviet communism. NATO and the Warsaw Pact of the Cold War were a symbol of mutual power show off, both in conventional weapons as well as nuclear competition. However, both sides brought anxiety, so that negotiations were performed to reduce competition. The fall of the Soviet Union and the dissolution of the Warsaw Pact caused the losing of NATO's opponent and policy direction.
\end{abstract}

Keywords: NATO, Containment Policy 


\section{PENDAHULUAN}

Berakhirnya Perang Dunia II tidak berarti perang telah selesai namun justru memasuki babak baru dalam sejarah dunia. Kekalahan di pihak fasisme mendorong demokrasi semakin berkembang. Namun demikian, demokrasi terpecah dalam beberapa paham lagi, diantaranya adalah demokrasi liberal yang diusung oleh Amerika Serikat dan demokrasi komunis yang diusung oleh Uni Soviet (Miriam Budiardjo, 2008:105). Perbedaan ideologi yang mereka usung akan membawa perubahan perimbangan kekuatan dari sistem multipolar ke bipolar. Pusat kekuatan bepindah dari Inggris dan Perancis ke Washington dan Moskow.

Uni Soviet dan Amerika Serikat sebagai negara yang memenangkan Perang Dunia II berambisi untuk menjadi negara adidaya. Uni Soviet memiliki kekuatan yang besar dengan pengaruhnya di berbagai tempat dan ditakuti oleh dunia. Kekuatan antara Amerika Serikat dan Uni Soviet sudah nampak lebih besar dibandingkan dengan negara-negara lain sejak Perang Dunia II berlangsung yang selanjutnya telah mengubah kekuatan potensial Amerika Serikat dan Uni Soviet menjadi kekuatan militer. Kenyataan ini memunculkan terminologi Negara super power (Joseph Nye, 1992: 90).

Pecahnya sistem politik demokrasi dan munculnya dua negara yang bersaing untuk menjadi negara yang besar, telah mempengaruhi kondisi politik dunia. pertentangan antara Amerika Serikat dan Uni Soviet nampak sangat tajam saat pembagian Jerman sebagai hasil Konferensi Postdam. Jerman dibagi menjadi empat kawasan, di mana tiga kawasan yang diduduki Amerika Serikat, Inggris dan Perancis berada di wilayah Jerman bagian Barat dengan menerapkan paham liberalisme, sedangkan satu wilayah yang berada di bawah Uni Soviet terletak di wilayah Jerman bagian timur yang mengusung paham komunisme. Tembok Berlin menjadi simbol pembagian dua negara tersebut.

Tidak hanya itu, Uni Soviet setelah Perang Dunia II terus melakukan invasi ke beberapa negara Eropa Timur, baik secara diplomasi maupun di bawah bayonet Tentara Merah, Uni Soviet mendirikan pemerintahan sosialis di negara-negara Eropa Timur. Gerak Uni Soviet ini meresahkan keadaan di Washington. Melihat keadaan seperti itu Parlemen Amerika Serikat segera melakukan tindakan untuk menanggapi aksi Uni Soviet tersebut. Berbagai pemikiran pun muncul, salah satunya George F Kennan mengusulkan sebuah politik "pembendungan" terhadap komunisme. Politik ini dikenal dengan nama Containment Policy. Usulan Kennan mendapatkan tindak lanjut dengan berbagai kebijakan yang dilaksanakan oleh Amerika Serikat untuk menghambat gerak Uni Soviet baik dalam bidang ekonomi, politik maupun militer.

Keadaan Eropa yang sedang terkoyak membuat Amerika Serikat mengambil tindakan. Amerika Serikat berusaha melakukan integrasi negara-negara Eropa Barat untuk bersatu menghadapi Komunisme Uni Soviet. Sebagai tindaklanjutnya Amerika Serikat dan negara-negara Atlantik Utara melakukan sebuah perundingan yang dikenal dengan The North Atlantic Treaty di Washington DC tanggal 4 April 1949. Hasil dari The North Atlantic Treaty adalah terbentuknya North Atlantic Treaty Organization (NATO) yang beranggotakan 12 negara di kawasan Amerika Utara dan Eropa Barat.

Negara-negara NATO menyetujui untuk menjaga perdamaian dan membangun kekuatan bersama dalam melawan setiap bentuk ancaman dari manapun. Amerika Serikat menjadi negara dengan kekuatan utama yang menggerakkan NATO dengan panglima pertama Eisenhower dari Amerika Serikat. Amerika Serikat sangat berkepentingan terhadap NATO, karena selain NATO berfungsi untuk menjaga keamanan dan perdamaian dunia juga difungsikan Amerika untuk menjaga stabilitas dan keamanan nasional Amerika Serikat sendiri, terutama untuk ambisi Amerika Serikat menjadi negara yang besar.

Berdasarkan paparan yang dikemukakan di atas artikel ini menarik untuk dikaji karena NATO merupakan implementasi pelaksanaan Containment Policy dalam bidang militer, yaitu sebuah politik pembendungan komu- 
nisme Uni Soviet. Selain itu NATO ternyata merupakan sebuah aliansi yang asimetris dengan adanya dominasi Amerika sebagai tonggak NATO, hal ini lah yang nantinya menyebabkan berbagai konflik dalam keanggotaan NATO. Sebagai sebuah usaha untuk membendung komunisme, pembentukan NATO membawa reaksi di pihak Uni Soviet sebagai pesaing Amerika Serikat.

\section{METODE}

Penelitian ini menggunakan metode sejarah kritis yang terdiri dari empat langkah yaitu: (1) Heuristik, kegiatan menghimpun jejak-jejak atau sumber-sumber sejarah, (2) Kritik Sumber, kegiatan meneliti jejak-jejak atau sumber-sumber sejarah yang telah dihimpun sehingga diperoleh sumber-sumber yang otentik dan terpercaya, (3) interpretasi merupakan penelaahan terhadap fakta-fakta sejarah, (4) Historiografi untuk menyampaikan sintesa yang diperoleh dalam bentuk karya tulis sejarah.

\section{PEMBAHASAN}

\section{Perimbangan Kekuatan Bipolar}

Amerika Serikat berusaha untuk menjaga keseimbangan di Eropa, yang sebelumnya dipercayakan kepada Inggris. Berpindahnya kekuatan Eropa, terutama Inggris dan Perancis ke Amerika Serikat sejak 1945 didasarkan atas keunggulan ekonomi Amerika Serikat, hal ini menciptakan sebuah tatanan baru dalam sistem perang yang ada. Penyelesaian Perang Dunia II telah mengakhiri pula kekerasan militer, namun dalam waktu yang bersamaan pula telah menciptakan basis perang yang baru. Pasca Perang Dunia II, superioritas kekuatan justru beralih dalam bentuk bipolar, yaitu antara sekulerisme moderat (demokrasi liberal) yang diwakili Amerika Serikat dengan sekulerisme radikal (komunisme) yang dianut Uni Soviet.

Kemunculan kekuatan bipolar tersebut melenyapkan kekuatan lama Eropa, yaitu Inggris, Perancis, Italia dan Astro-Hongaria. Persaingan yang semula berpangkal dari perbedaan pandangan mengenai masa depan bekas negara-negara jajahan beserta wilayah pendudukan, akhirnya menjadi suatu persaingan terbuka. Di satu pihak Amerika dan sekutunya menginginkan agar di bekas negara jajahan dan wilayah pendudukan dipersiapkan suatu pemerintahan yang demokratis. Sedangkan Uni Soviet ingin tetap mempertahankan pengaruhnya, sehingga di negara-negara bekas jajahan dan wilayah pengaruhnya dibentuk pemerintahan sosialis yang tidak memusuhi Uni Soviet. Dua idelogi tersebut sangatlah berbeda dan bertentangan baik dalam teori maupun pelaksanaannya. Hal ini mendorong dua kekuatan bipolar tersebut untuk menyebarkan ideologi yang mereka usung dan memperluas hegemoni mereka.

Sebuah ideologi tidak hanya berorientasi pada masalah politik, namun mengacu pula pada sistem perekonomian. Dapat dilihat bahwa keadaan perekonomian sebuah negara diukur berdasarkan ideologi yang mereka anut. Padahal dalam kenyataan hal tersebut tidak dapat dijadikan sebagai patokan. Masing-masing ideologi menerapkan prinsip kerja yang berbeda, sehingga tidak jarang prinsip-prinsip tersebut saling bertentangan. Pertentangan juga dapat terjadi meskipun paham dasar yang dianut sama. Konflik ideologi bukanlah merupakan sesuatu hal yang baru. Hal ini muncul seiring dengan kemunculan dan perkembangan pemikiran manusia.

Konflik ideologi yang paling berpengaruh di dunia yaitu antara liberlisme dan komunisme. Konflik ini telah ada sebelum Perang Dunia II namun menjadi semakin besar setelah kemenangan sekulerisme dan demokrasi atas fasisme dalam Perang Dunia II. Hal ini tidak berarti keadaan dunia serta merta menganut satu paham sekulerisme dan demokrasi saja. Semua konsep tersebut memakai istilah demokrasi yang menurut asal katanya berarti "rakyat berkuasa" (Miriam Budiardjo, 2008: 50).

Menurut teori Duverger, bahwa liberalisme dan komunisme memiliki tujuan akhir yang sama, yaitu terbentuknya masyarakat yang makmur dengan terpenuhinya sebagian kebutuhan masyarakat (Mawasdi Rauf, 2001:47). Perimbangan bipolar membawa 
dunia dalam tatanan perang yang baru, yaitu Perang Dingin. Perang Dingin berawal dari sebuah kepentingan dua negara besar yang pada kenyataannya mereka membawa ideologi yang saling bertentangan. Sebagai negara besar, Uni Soviet memainkan peranan penting dalam membangun tatanan dunia baru. Uni Soviet menganggap dirinya sebagai raksasa yang akan menguasai dunia karena kepentingan-kepentingannya yang begitu luas, baik di kawasan Eropa, Pasifik dan kawasan lain.

Sebagai langkah awal Uni Soviet mendirikan negara-negara sosialis di Eropa Timur yang nantinya akan dijadikan sebagai negara satelitnya untuk melindungi perbatasan Uni Soviet demi pertahanan dalam negeri Uni Soviet. Gerakan Uni Soviet setelah mampu menakhlukkan Eropa Timur maka akan bergerak ke Eropa Tengah dan Eropa Barat, sehingga akhirnya dapat menguasai seluruh Eropa. Kemampuan Uni Soviet untuk menakhlukkan Eropa Timur menimbulkan kekhawatiran di pihak Amerika Serikat bahwa Eropa Timur akan dijadikan sebagai batu loncatan untuk mengusai seluruh Eropa dan dunia.

Ketidak cocokan antara Amerika Serikat dan Uni Soviet telah ada jauh lama sebelum Perang Dingin berlangsung. Perbedaan ini berakar pada ideologi dan sistem sosial yang saling bertentangan, bahkan saling memusuhi. Contohnya terlihat dalam pembagian "zona pengaruh" setelah Jerman menyerah tanpa syarat kepada sekutu. Setelah Jerman mampu dikalahkan, salah satu tujuan utama dari pasukan sekutu adalah untuk demokratisasi Jerman. Uni Soviet berpendapat bahwa kepitalisme merupkan sumber permasalahan dan konflik, sedangkan Amerika Serikat beranggapan bahwa sosialisme maupun komunisme merupakan suatu bentuk penyelewengan terhadap demokrasi, karena tidak ada kebebasan, di mana kebebasan merupakan salah satu pilar demokrasi.

Amerika Serikat, Inggris dan Perancis beranggapan bahwa demokrasi yang akan dilaksanakan di Jerman seperti halnya pemilihan bebas, pers yang merdeka, kemerdekaan mengadakan perkumpulan politik, kebe- basan beragama, berfikir dan berbicara, persamaan menurut hukum, hak untuk menentang pemerintah, hak untuk memilih pekerjaan sendiri, hak untuk membentuk serikat-serikat pekerjaan untuk bergerak bebas dalam negeri sendiri (Ebenstein, 1961: 95). Hal tersebut mengacu pada konsep-konsep demokrasi dan liberalisme yang telah diterapkan di Amerika Serikat beserta negara sekutunya.

Pemikiran Marxisme-Leninisme bertolak dari teori konflik dan revolusi, sedangkan pandangan Amerika Serikat bertolak dari kebebasan politik tirani. Kebebasan adalah tujuan tertinggi dalam hirarkinya. Dalam perspektif Amerika Serikat bahwa pemerintahan yang demokratis dan bangsa yang bebas dianggap mencintai perdamaian, sedangkan tirani dan kediktatoran mempunyai kecenderungan untuk melakukan ekspansi ke luar batas wilayah mereka dan merampas segala sesuatu yang ada di dalamnya. Tirani di suatu negara yang tidak terkontrol akan menjadi ancaman bagi seluruh dunia. Sebagai cerminannya adalah kekuasaan Hitler, dan sekarang yang perlu diwaspadai adalah Uni Soviet.

Pemerintahan demokratis menurut komunisme bukanlah sebuah pemerintahan rakyat, namun sebuah politik yang dijalankan untuk kepentingan mayoritas, bukan didasarkan pada kepentingan minoritas. Pandangan ini membantah konsep demokrasi barat yang dijalankan untuk rakyat berdasarkan pada kepentingan individu. Uni Soviet justru mengatakan bahwa Jerman Barat merupakan sebuah negara yang diktator karena kepentingan rakyatnya tidak ditentukan oleh satu partai yang benar-benar tahu akan kepentingan rakyat Jerman (Ebenstein, 1961: 96).

Uni Soviet mengatakan bahwa pelaksanaan demokrasi yang seutuhnya berada dalam pemerintahan Jerman Timur, karena alat-alat produksi beserta penyelenggaraannya telah diolah oleh pemerintah untuk kepentingan rakyat. Perang Dunia II juga memicu proses dekolonisasi yang mengubah peta politik dunia secara mendasar. Masing-masing adikuasa berusaha untuk menanamkan pengaruhnya di negara-negara baru merde- 
ka tersebut, dengan demikian akan melibatkan beberapa negara baru tersebut terlibat dalam Perang Dingin.

Kelumpuhan Eropa Barat dan Tengah pasca Perang Dunia II memastikan terpusatnya politik dunia di masa yang akan datang di Washington dan Moskow, tidak lagi di London dan Paris. Namun perubahan kekuatan bipolar ini diikuti dengan permusuhan ideologis yang sengit antara dua kekuatan utama dunia yang justru membuka zaman konflik, kecurigaan, persaingan dan kesalahpahaman, bahkan berujung pada perang total.

Kekuatan kapitalis barat terus melakukan suatu propaganda untuk melawan kemampuan komunis. Namun Uni Soviet tetap bertahan dan justru melibatkan dirinya dalam pembentukan suatu tata baru pemerintahan di Eropa Timur, bekerja dengan sekutu-sekutu barunya. Dalam hal ini negara-negara satelitnya tidak terpengaruh oleh propaganda barat dan tetap setia pada sosialis.

Perimbangan bipolar ini muncul karena di antara negara-negara kapitalis, Amerika Serikat merupakan ancaman yang paling besar bagi Uni Soviet, sedangkan di antara negara-negara sosialis Uni Soviet merupakan kekuatan yang dapat mengancam kebebasan dunia. Maka dari itu pada awal-awal bipolaritas dua negara ini menciptakan hegemoni militer dan ekonomi yang dimaksudkan untuk membendung komunisme Uni Soviet dan revolusi sosialis. Bipolaritas ini berangkat pula dari pengalaman Amerika Serikat membantu Eropa dalam dua kali Perang Dunia. Amerika Serikat beranggapan bahwa tanggungjawab politik dunia merupakan suatu kewajiban yang tidak dapat dilepaskannya sebagai negara demokrasi terkuat.

Sebagai polisi dunia, menjaga suatu PaxAmericana global, bagi Uni Soviet merupakan suatu ancaman yang tidak dapat dibiarkan bagi pertahanan Uni Soviet dan MarxismeLeninisme di seluruh dunia. Pandangan Uni Soviet atas Amerika Serikat merupakan pangkal tolak kebijakan luar negeri Moskow yang arti pentingnya hanya dapat diungguli oleh imperatif ideologi. Pandangan Uni Soviet berpangkal dari kombinasi kepentingan nasional Uni Soviet dan prinsip-prinsip ide- ologi komunis.

Kekuatan militer imperialis sangat besar, sehingga menantang secara langsung sistem imperial merupakan suatu hal yang sangat sulit. Namun Uni Soviet harus mempertahankan negara-negara komunis yang sudah ada. Sebagai kekuatan imperialis utama, Amerika Serikat mempunyai peran khusus dalam sistem internasional. Amerika Serikat juga sangat terampil dalam mengembangkan posisi sebenarnya di balik pengamanan moral dan ideologis yang membingungkan. Dunia kapitalis Amerika Serikat mengepung sosialisme dan hanya Uni Soviet yang mampu melindungi dan menunjukkan gerakan revolusioner dunia.

\section{Doktrin Containment Policy}

Containment Policy merupakan sebuah strategi Blok Barat dalam Perang Dingin sejak tahun 1946 untuk menahan ekspansi politik, daerah dan pengaruh Blok Timur. Hal ini dilakukan dengan membuat garis status quo dan tidak boleh dilewati. Kebijakan luar negeri Amerika Serikat didasarkan pada asumsi bahwa Uni Soviet adalah musuh utamanya, menjalankan politik luar negeri yang ekspansif, oleh karena itu perlu dihentikan atau dibendung Kebijakan ini diterapkan melalui pembentukan garis pembendungan dan tahap berikutnya adalah membangun kekuatan di sepanjang garis tersebut. Jika Uni Soviet berusaha untuk menembus garis tersebut Amerika Serikat akan membalasnya dengan cara yang realistik.

Dasar munculnya konsep Containment Policy adalah dokumen Long Telegram dan The Sources of Soviet Conduct. George F Kennan sebagai seorang Kreminologi mempelajari berbagai sepak terjang Uni Soviet (MacNamara, 1990: 36). Akhirnya melalui hubungan transmisi Kennan berhasil meloloskan sebuah telegram yang dikenal dengan sebutan Long Telegram. Telegram tersebut cukup mencengangkan pemerintah Amerika Serikat, karena di dalam Long Telegram terdapat uraian Kennan yang menjelaskan tentang karakter Uni Soviet yang dijadikan sebagai landasan kebijakan politik dan tindakan yang seharusnya dilakukan untuk mem- 
bendungnya. Secara singkat Long Telegram membahas tentangbasic features of post-war Soviet outlook, background of this outlook, its projection in practical policy on social level, its projection on unofficial level, and practical deductioms from standpoint of policy.

Berdasarkan uraian isi Long Telegram, maka memunculkan banyak analisis mengenai karakter Uni Soviet dan cara untuk menanggulanginya. Setahun kemudian Kennan mempublikasikan sebuah tulisan yang sangat terkenal di Journal Foreign Affairs dengan nama samaran X. Artikel ini merupakan sebuah analisis yang elegan dengan judul Sources of Soviet Conduct (MacNamara, 1990: 40). Artikel ini merupakan panguatan Kennan terhadap Long Telegram yang pernah dikirimkan. Dari artikel ini membawa karakteristik kebijakan politik Amerika Serikat untuk menghadapi Uni Soviet di masa-masa yang akan datang. Menurut Kennan politik pembendungan harus diramu melalui kekuatan militer yang canggih, kepekaan mengenai waktu dan sentuhan yang lembut tanpa Uni Soviet merasa dipermalukan, sehingga tidak memungkinkan pecahnya perang, sementara pengaruh Uni Soviet dapat dibendung atau dikurangi.

Kennan mendasarkan pandangannya terhadap Uni Soviet tersebut pada tiga elemen fundamental pemikiran Stalin yang menjadi instrumen dalam membentuk kebijakan politik dalam negeri dan luar negeri Uni Soviet (MacNamara, 1990: 36). Dasar pemikiran tersebut adalah.

1) Pertama, Stalin tidak membiarkan oposisi di dalam pemerintahannya atau di negara-negara satelit, Eropa Timur. Menurut Kennan bahwa politik seperti itu merupakan sebuah kebohongan mental Uni Soviet untuk memimpin dunia, hal ini terwujud dalam karakteristik dan ideologi mereka, di sini tidak ada oposisi agar mereka (partai komunis) mendapat pengakuan resmi, seperti memiliki jasa atau pembenaran terhadap segala sesuatu.

2) Kedua, Uni Soviet membutuhkan pencitraan dari sebuah lawan untuk membenarkan penindasan luar negeri dan dalam negeri. Kennan membuat sebuah kesimpulan untuk Uni Soviet bahwa pengolahan wilayah merupakan awalan cerita ringan dari sikap keras yang menyebabkan permusuhan luar negeri

3) Ketiga, meskipun Stalin tidak dapat optimis terhadap hasil dari potensi perang Amerika Serikat-Uni Soviet, selama masa-masa awal Perang Dingin pandangan dunianya didasarkan pada konflik yang meningkat antara sosialisme dan kapitalisme. Anggapan Uni Soviet bahwa konflik tersebut merupakan pembawaan lahir antagonisme antara kapitalisme dan sosialisme.

Kennan berpendapat bahwa Uni Soviet jauh lebih lemah daripada Amerika Serikat dan masyarakat Uni Soviet dibentuk atas dasar kekurangan yang pada akhirnya akan melemahkan kekuatan potensial mereka. Kekuatan ini nantinya akan mempengaruhi kehidupan perekonomian mereka. Uni Soviet berpendapat bahwa harus memperbaiki perekonomian mereka untuk membangun dunia. Hal ini sangat menarik karena keadaan perekonomian Uni Soviet yang buruk tidak berpengaruh terhadap kekuatan militer mereka.

Kennan beranggapan bahwa Uni Soviet tertelungkup setelah Perang Dunia II dan tidak memiliki rencana untuk melakukan penyerangan ke Eropa Barat. Kennan baru mengerti ancaman tersebut setelah Uni Soviet mencoba untuk menyebarkan ideologi politik mereka. Hal ini terlihat dari gerak komunis Italia dan Perancis yang berusaha untuk menduduki kursi kabinet. Kennan menjelaskan bahwa gerakan komunis terlihat berbahaya apabila dukungan partai komunis ke Moskow meraih kekuatan di beberapa negara Eropa Barat, khususya Perancis dan Italia. Hal ini lah yang membuat kecemasan Washington karena Uni Soviet selalu mampu untuk melakukan penetrasi ideologi politiknya.

Pemikiran Kennan ini bersumber pada filsafat pembendungan (Containment). Kennan menyatakan bahwa kebijakan Soviet bersumber pada ideologi Marxisme-Leninisme yang menuntut perjuangan dan perlawanan global terhadap kapitalisme. Menurut Ken- 
nan bahwa tanggung jawab untuk melawan kebijaksanaan konflik tanpa kelas ini jatuh pada Amerika Serikat yang harus mendasarkan tindakan-tindakannya atas prinsip pembendungan kekuatan Soviet di dalam batas-batasnya yang ada sampai adanya perubahan-perubahan internal di dalam kepemimpinan Uni Soviet yang mau meninggalkan maksud-maksud agresi (Maswadi Rauf, 2001:47).

Pandangan ini kemudian dianut oleh presiden Harry S Truman dan diungkapkan dalam pidato di depan Kongres pada tanggal 12 Maret 1947. Pidato ini dikenal dengan nama Doktrin Truman. Dalam pidatonya Truman menyejajarkan agresi komunis dengan angresi Nazi. Politik pembendungan ini diupayakan oleh Amerika Serikat dikarenakan beberapa hal yang mempengaruhinya, baik itu faktor dari dalam negeri maupun luar negeri (Julius Pratt, 1965: 460-461).

\section{NATO sebagai Pelaksana Doktrin Con- tainment Policy}

Pembagian Jerman dalam empat zona mengakibatkan masing-masing pendudukan militer di negara tersebut melakukan kebijakan masing-masing. Zona Amerika Serikat merupakan zona yang paling cepat merealisasikan hasil Konferensi Postdam. Kebijakan pemerintahan pendudukan antara Amerika Serikat, Inggris dan Perancis memiliki kesamaan, namun sangat bertentangan dengan Uni Soviet. Pertentangan ini terus berlanjut yang dibumbui dengan adanya ekspansi komunisme Uni Soviet ke kawasan Eropa Timur.

Amerika Serikat, Perancis dan Inggris berdiskusi untuk menggabungkan zona mereka menjadi satu republik tunggal dengan pemerintahan sendiri. Tetapi Uni Soviet menolak rencana untuk menyatukan Jerman dan diskusi tingkat menteri keempat negara tentang Jerman menemui jalan buntu. Ketika kekuatan barat mengumumkan niat untuk menciptakan negara federal dari zona milik mereka, Stalin memberikan respon dengan melakukan beberapa kebijakan, yaitu pembersihan politik dalam negeri, militansi dalam kebijakan luar negeri dan konsolidasi Eropa Timur, termasuk pembentukan cominform, kudeta Ceko dan blokade Berlin.

Blokade Berlin mulai dilaksanakan tanggal 23 Juni 1948 dengan menutup semua alat transportasi dan perhubungan antara Berlin dan pendudukan Jerman zona barat (Temple Wanamaker, 1964:128). Hal ini dilakukan sebagai salah satu usaha untuk melindungi Jerman Timur dari aliansi lain yang bersatu di wilayah Jerman bagian Barat. Para pemimin Amerika Serikat takut hilangnya Berlin akan menjadi awal hilangnya Jerman dan nantinya seluruh Eropa. Oleh sebab itu pasukan Inggris dan Amerika Serikat mengirimkan persediaan ke Berlin dengan menggunakan angkutan udara (airlift). Suatu sistem pengangkutan penumpang dan barang melalui udara, biasanya dilakukan ke tempat-tempat yang terisolir, hubungan darat terputus maupun tempat yang sukar ditempuh dengan jalan darat.

Selain itu dominasi Uni Soviet di Eropa Timur mengkhawatirkan barat. Ekspansi yang dilakukan Uni Soviet membawa kecemasan Amerika Serikat dan negara-negara sekutunya. Kecemasan di pihak Eropa membawa mereka untuk melakukan kerjasama, baik dalam bidang ekonomi maupun politik. Amerika Serikat memimpin usaha untuk menciptakan persekutuan militer. Langkah pertama integrasi dalam usaha pertahanan Eropa Barat ditandai dengan ditandatanganinya The Brussel Treaty pada 17 Maret 1948, satu bulan setelah pukulan mendadak Uni Soviet ke Czechoslovakia .

Brussel Treaty diprakarsai oleh 5 negara, yaitu Belgia, Belanda, Luxemburg, Inggris dan Perancis. Hasil dari kesepakatan tersebut adalah berdirinya Brussel Treaty Organization (BTO). Negara-negara yang menandatangani kesepakatan Brussel tersebut akhirnya melakukan perundingan dan negoisasi dengan Amerika Serikat dan Kanada untuk membentuk sebuah aliansi pertahanan yang lebih besar guna mencegah gerak Uni Soviet dengan ideologi komunisnya.

Resolusi Vandenberg merupakan bagian pembukaan dibentuknya organisasi pertahanan bersama untuk sebuah kepentingan dan ambisi yang berbahaya dalam pencarian keamanan bersama. Hasil perjanjian adalah 
terbentuknya aliansi pertahanan bersama yang ditandatangani tanggal 14 April 1949 oleh 12 negara di kawasan Eropa Barat dan Amerika Utara.

Negara-negara anggota NATO menyetujui perjanjian untuk saling menjaga perdamaian dan membangun kekuatan bersama dalam melawan setiap bentuk ancaman dari manapun. Prinsip NATO tertuang dalam artikel V dari The North Atlantic Treaty yang menyatakan bahwa salah satu anggota NATO mendapat serangan atau ancaman dari pihak lain, maka diartikan sebagai serangan terhadap semua anggota NATO, termasuk penggunaan senjata militer. NATO dibentuk di bawah kendali menteri luar negeri, menteri pertahanan dan menteri keuangan masing-masing negara anggota. Markas besar NATO berada di Brussel. Markas Besar ini disebut dengan nama SHAPE (Supreme Headquarters Allied Power in Europe) dengan komandan tertinggi pertama adalah Eisenhower.

NATO merupakan salah satu wujud implementasi doktrin containment Amerika Serikat dalam menghadapi kekuatan negara induk komunis, yaitu Uni Soviet. NATO didirikan dengan tujuan untuk membendung gerakan militer Uni Soviet di kawasan Eropa, terutama Eropa Utara dan Barat dengan memadukan persenjataan konvensional dan nuklir guna melindungi negara barat dari kemungkinan ancaman Uni Soviet bersama negara-negara satelitnya.

Hubungan antara negara-negara Eropa Barat dan Amerika Utara memiliki tujuan politik yang didukung dengan kerjasama dalam bidang militer, ekonomi dan ilmu pengetahuan. NATO dibentuk untuk menjaga kebebasan dan warisan budaya bersama negara-negara anggota dengan meningkatkan stabilitas dan kesejahteraan di wilayah Atlantik Utara. Keberadaan NATO dimaksudkan untuk membangun rasa percaya diri anggotanya, sehingga dapat memperkuat kekuatan barat secara moral dan material untuk melawan kemungkinan bahaya yang diakibatkan ekspansi komunisme Uni Soviet (Temple Wanamaker, 1964: 128).

Sebagai sebuah aliansi pertahanan, NATO berfungsi sebagai sarana untuk menjangkau tujuan keamanan bersama melawan tindakan yang mengancam kedaulatan negara-negara anggota sesuai dengan piagam Perjanjian Atlantik Utara. NATO memainkan perannya untuk membentuk garis pertahanan terdepan dalam melawan ancaman Uni Soviet dan negara-negara satelitnya, baik dalam militer maupun ideologi.

\section{Dampak berdirinya NATO}

Semenjak permulaan tahun 1949, kementrian luar negeri Uni Soviet menentang pembentukan aliansi NATO. Pembentukan NATO dan usaha-usaha membentuk pemerintahan demokrasi di Eropa Timur dipandang sebagai ancaman bagi keamanan Uni Soviet. Pemerintahan Uni Soviet menghendaki suatu konferensi keamanan yang melibatkan semua negara Eropa untuk membahas suatu pakta tidak saling menyerang dan pertahanan kolektif. Para penandatangan pakta sebaiknya memberi jaminan tidak saling menyerang dan menghindari ancaman maupun penggunaan kekuatan. Koalisi perseteruan hendaknya dihindari, dan bila satu atau beberapa ngara penandatangan diserang, yang lainnya harus menganggap sebagai serangan terhadap mereka pula dan memberi bantuan militer. Sistem ini hendaknya diadakan dengan membentuk komite-komite konsultatif politis dan militer (Walter S Jones, 1993:37).

Negara-negara barat menolak usul ini, meragukan maksud-maksud Uni Soviet dan dalam pandangan Uni Soviet lebih suka memelihara jaringan alaiansi perseteruan dan agresif disertai harapan mereka dapat memperbaharui kapitalisme di Eropa Barat atau sekurang-kurangnya mencegah penyebaran lebih jauh gerakan-gerakab revolusioner. Ini memaksa negara-negara sosilais membentuk persekutuan tandingan, Pakta Warsawa untuk mempertahankan diri. Pakta Warsawa memiliki ketentuan bahwa seandainya aliansi Atlantik Utara berakhir, maka pakta ini secara otomatis juga berakhir. Maka menurut pandangan Uni Soviet bahwa tanggung jawab sistem aliansi Perang Dingin ada pada pihak barat. 
Pakta Warsawa merupakan respon langsung terhadap masuknya militer Jerman Barat ke dalam kesatuan NATO tahun 1955. Berdasarkan perjanjian tersebut bahwa negara-negara yang tergabung dalam Pakta Warsawa berkewajiban memberikan batuan militer kepada sekutu mereka apabila terjadi serangan dari pihak lain. Selain itu setiap negara juga berkewajiban memerangi ancaman terhadap "bangunan sosialis" di negaranya masing-masing.

Pakta Warsawa dan NATO menjadi lambang persaingan militer dan Perang Dingin. Namun sampai berakhirnya Perang Dingin belum pernah terungkap adanya kontak senjata secara terbuka antara kedua persekutuan militer ini. Apalagi kontak senjata nuklir. Banyak pakar berpendapat bahwa kedua negara takut untuk menggunakan nuklir guna mengakhiri perselisihan dan persaingan di antara mereka, karena menyadari betapa dasyatnya penggunaan nuklir tersebut.

Rasio kekuatan konvensional pakta Warsawa tetap unggul dua banding satu (Walter S Jones, 1993: 89). Dalam perlengkapan pertempuran dan dukungan udara, kedua pihak hampir seimbang dalam pesawat tempur pembom. Namun Pakta Warsawa unggul hampir enam banding satu dalam pesawat pengintai. Selain dalam kekuatan tempur darat dan udara, Pakta Warsawa juga unggul dalam kekuatan laut. Pakta Warsawa dapat mengungguli NATO dalam kapal penjelajah berat, kapal patroli, kapal perang ranjau, peluru kendali balistik dan kapal selam jarak jauh.

Persaingan senjata baik senjata konvensional maupun nuklir membawa kekhawatiran semua pihak apabila senjata nuklir benar-benar digunakan dalam perang. Akibat yang ditimbulkan dari penggunaan senjata nuklir sangat berbahaya. Secara keseluruhan kekuatan operasi nuklir Amerika Serikat dilengkapi dengan sekitar 14.000 hulu ledak berkekuatan 8,4 triliun ton TNT, sedang sistem strategis nuklir Uni Soviet dilengkapi dengan 19.000 hulu ledak. Di Eropa Pakta Warsawa dan NATO saling berhadapan tidak hanya dengan MIRV tetapi juga denga ratusan ribu tentara, persenjataan konvensional dan milyaran megaton TNT yang terkandung dalam senjata-senjata nuklir taktis yang siap ditembakkan.

\section{SIMPULAN}

Perang Dunia II merupakan sebuah perang yang membawa perubahan perpolitikan dunia, terutama di kawasan Eropa. Berakhirnya Perang Dunia II ditandai dengan menyerahnya Jerman dan Jepang pada sekutu. Penguatan terhadap berakhirnya Perang Dunia II ditandai melalui Perjanjian Postdam yang diadakan tanggal 17 Juli-2 Agustus 1945. Perjanjian Postdam mengatur masalah negara-negara yang kalah perang, diantaranya Jerman dan Jepang. Perjanjian Postdam berdampak pada pembagian wilayah Jerman sebagai sebuah negara yang besar. Dari sini muncul persaingan di antara Amerika Serikat dan Uni Soviet yang berambisi untuk menjadi negara besar dan menguasai dunia. Keadaan ini membawa perimbangan kekuatan berubah dari multipolar menjadi bipolar.

Namun demikian kekuatan bipolar ini sebenarnya tidaklah seimbang. Uni Soviet hanyalah sebuah negara besar yang memiliki pengaruh secara regional dan tertinggal dalam bidang teknologi. Sedangkan Amerika Serikat memiliki pengaruh di seluruh dunia. Usaha Uni Soviet untuk menjadi sebuah negara besar ini dilakukan melalui ekspansi ke beberapa negara di Eropa Timur, baik secara damai maupun di bawah bayonet Tentara Merah. Akhirnya Uni Soviet mampu mendirikan negara sosialis di Polandia, Bulgaria, Cekoslovakia, Rumania, Albania, Jerman Timur, dan Hungaria.

Ekspansi Uni Soviet ini memunculkan pertentang dalam Parlemen Amerika Serikat. Muncullah George F Kennan dengan Filsafat pembendungannya. Kennan mengirimkan telegram panjang dari Moskow kepada Pemerintah Amerika Serikat. Telegram ini disebut dengan Long Telegram, telegram berisikan tentang dasar-dasar kebijakan luar negeri Uni Soviet. Hal ini sangatlah mencengangkan Kongres Amerika Serikat. Satu tahun kemudian Kennan mempublikasikan tulisannya dalam Jurnal Foreign Affairs dengan 
judul The Sources of Soviet Conduct. Tulisan ini merupakan penguatan terhadap Long Telegram. Presiden Harry S Truman mengadopsi politik ini dan mengimplementasikannya dalam kebijakan politik luar negeri Amerika Serikat, salah satunya dalam bidang militer dengan didirikannya NATO (North Atlantic Treaty Organization).

Berdirinya NATO membuat langkah Amerika Serikat untuk menanggulangi komunisme dan menandingi Uni Soviet dapat diwujudkan dengan mudah. NATO dan Pakta Warsawa sebagai simbol Perang Dingin menjadi wahana persaingan senjata konvensional dan nuklir Uni Soviet dan Amerika Serikat. Namun demikian perlombaan persenjataan dua adikuasa ini menimbulkan permasalahan dan kekahwatiran negara-negara Eropa, maka dari itu dilakukan usaha pembatasan persenjataan, baik konvensional maupun nuklir.

\section{UCAPAN TERIMA KASIH}

Terima kasih kepada pembimbing yang membimbing proses penelitian ini serta semua pihak yang turut membantu proses penelitian.

\section{DAFTAR PUSTAKA}

Ebenstein, W. 1961. Isme-isme dewasa ini: komunisme, fasisme, kapitalisme, sosialisme: Today's isms. Jakarta: Swada.

Jones, Walter S. 1993. "The Logic of
International Relations", a. b, Budiono K, Logika Hubungan Internasional Persepsi Nasional 1. Jakarta: Gramedia Pustaka Utama.

Jones, Walter S. 1993. "The Logic of International Relations", a. b, Budiono $\mathrm{K}$, Logika Hubungan Internasional, Kekuasaan, Ekonomi-politik Internasional dan Tatanan Dunia 2. Jakarta: Gramedia Pustaka Utama.

Kennan and Containment. 1947. Tersedia pada http://www. state. gov/r/pa/ho/ time/cwr/17601. htm. Diakses tanggal 9 Juni 2009.

Miriam Budiardjo. 2008. Dasar-Dasar Ilmu Politik. Jakarta: Gramedia Pustaka Utama.

Nye, Joseph. 1992. "Bound to Lead: The Changing Nature of American Power", a. b, Budhy Kusworo, Memimpin Dunia: Sifat Kekuatan Amerika yang Berubah. Jakarta: Yayasan Obor Indonesia.

Pratt, Julius. W. 1965. A History of United States Foreign Policy. New Jersey: Prentice Hall Inc.

Rauf, Maswadi. 2001. Konsensus dan Konflik Politik sebuah Penjajagan Teroris. Jakarta: Dirjen Dikti Depdiknas RI.

Wanamaker, Temple. 1964. American Foreign Policy Today. New York: Bantam Books. 